\title{
Accumulation of Antioxidants in Apple Peel as Related to Preharvest Factors and Superficial Scald Susceptibility of the Fruit
}

\author{
Cynthia L. Barden ${ }^{1}$ and William J. Bramlage \\ Department of Plant and Soil Sciences, University of Massachusetts, Amherst, MA 01003
}

\begin{abstract}
Additional index words. ascorbic acid, carotenoids, glutathione, Malus domestica, $\alpha$-tocopherol
Abstract. Antioxidants are believed to protect against the oxidation of $\alpha$-farnesene to conjugated trienes in apple (Malus domestica, Borkh.) peel, thus providing resistance against superficial scald development. We conducted three experiments in which apples were a) harvested weekly, during which they were exposed to increasing hours at <10C during ripening; b) induced to ripen with no hours at $<10 \mathrm{C}$ by applying ethephon; and c) enclosed in paper bags as they ripened. Inducing ripening with ethephon increased total water-soluble reducing compounds and percentage inhibition of lipid oxidation of peel extracts, increased concentrations of $\alpha$-tocopherol, carotenoids, and ascorbic acid in peel, but only slightly reduced scald. Delayed harvests increased all of these antioxidants except ascorbic acid and greatly reduced scald development. Bagging fruit before ripening decreased $\alpha$-tocopherol, carotenoid, and ascorbic acid concentrations, decreased total water-soluble reducing compounds, and increased scald development. We conclude that changes in these antioxidants probably are affected more by ripening and light intensity than by low temperature before harvest. Chemical name used: (2-chloroethyl)phosphonic acid (ethephon).
\end{abstract}

Superficial scald of apples is a disorder that develops during storage. Accumulation of the volatile sesquiterpene $\alpha$-farnesene and its subsequent oxidation to conjugated trienes have been related to scald development (Huelin and Coggiola, 1968; Huelin and Murray, 1966; Meigh and Filmer, 1969). Anet (1972) reported that immature apples generally do not produce more $\alpha$-farnesene than more mature apples but that they develop much more scald. Thus, their inability to prevent the oxidation of $\alpha$-farnesene, possibly due to a less efficient antioxidant system, may be responsible for their higher susceptibility. In a study of 16 apple cultivars, 11 endogenous antioxidants were detected, although only three tocopherols were identified (Anet, 1974). Five of the detected antioxidants, including $\alpha$-tocopherol, were found in all cultivars. There are many antioxidants that absorb at $\approx 200 \mathrm{~nm}$ (Anet, 1974), and Meir and Bramlage (1988) found a negative correlation between absorbance at $200 \mathrm{~nm}$ (OD 200) of a hexane extract of apple surfaces and the scald susceptibility of 'Cortland' apples. Since total antioxidant activity of the apple peel correlated with the OD 200 values, Meir and Bramlage (1988) proposed that OD 200 values estimated total antioxidant activity and may be used to predict scald susceptibility. However, additional data have not shown consistent correlation of OD 200 values and scald susceptibility (Bramlage et al., 1993).

Our study examined the hypothesis that the development of scald resistance in apples results from increased antioxidant activity in the fruit peel before harvest. These endogenous antioxidants may inhibit the oxidation of $\alpha$-farnesene and thus block the sequence of events suggested by Huelin and Coggiola (1970). Factors examined for effects on scald resistance were preharvest temperature (as accumulated hours at $<10 \mathrm{C}$ ), ripening, and expo-

Received for publication 28 Oct. 1992. Accepted for publication 17 June 1993 Massachusetts Agricultural Experiment Station paper no. 3075. This research was supported in part by experiment station project no. 517, and by grant no. US-1525-88 from the U.S.-Israel Binational Agricultural Research and Development Fund. The cost of publishing this paper was defrayed in part by the payment of page charges. Under postal regulations, this paper therefore must be hereby marked advertisement solely to indicate this fact.

${ }^{1}$ Current address: Pennsylvania State Univ., Fruit ResearchLab., Box 309, Biglerville, PA 17307. sure to light. Of these, low temperature greatly reduced, ripening only slightly reduced, and low light levels during ripening substantially increased susceptibility (Barden and Bramlage, 1994). Thus, according to the hypothesis, preharvest hours at $<10 \mathrm{C}$ should have caused endogenous antioxidants to increase substantially, ripening should have caused a slight increase to occur, and low light levels should have reduced antioxidant activity substantially. Here we report chemical analyses of fruit peel at harvest that test the hypothesis.

\section{Materials and Methods}

Field experiments. Experiments were conducted at the Horticultural Research Center, Belchertown, Mass., 1990-91. To measure effects of preharvest temperature, 'Cortland' and 'Delicious' apples were harvested at about weekly intervals during the harvest season, and cumulative preharvest hours at $\angle 10 \mathrm{C}$ at each harvest were obtained from a recording thermometer in the orchard. At each harvest, $\approx 100$ fruit/tree were selected at random. There were six two-tree replications per cultivar. To assess effects of ripening, ethephon $\left(0.25\right.$ or $0.5 \mathrm{~g} \cdot$ liter $\left.^{-1}\right)$ plus surfactant was applied to 'Cortland' trees to the drip point on 20 Aug., and $\approx 100$ fruit/tree were harvested on 1 and 6 Sept. Five two-tree replications were used. To assess effects of light levels, $\approx 200$ fruit/tree of 'Cortland' were enclosed in brown kraft paper bags in mid-August, and $\approx 100$ fruit/tree were harvested on 1 and 9 Oct. This experiment used five single-tree replications.

Sampling fruit after harvest. In all experiments, on the day of sampling, 10 fruit/sample were 1) tested for ripeness (Barden and Bramlage, 1994), 2) extracted in $100 \mathrm{ml}$ of high-performance liquid chromatography (HPLC)-grade hexane (Fisher Scientific, Pittsburgh) according to Meir and Bramlage (1988), and 3) the peel was freeze-dried and stored at $-20 \mathrm{C}$ until analysis. The remaining fruit were stored at $0 \mathrm{C}$ for 20 weeks, then transferred to $20 \mathrm{C}$ for 1 week and examined for scald development.

Percentage inhibition of lipid oxidation. To assay percentage inhibition of oxidation as an indication of lipid-soluble antioxidant activity, $0.5 \mathrm{~g}$ of freeze-dried apple peel was extracted overnight in $10 \mathrm{ml}$ of HPLC-grade hexane at room temperature in darkness. The 
procedure of McKersie et al. (1982) was used, as modified by Meir and Bramlage (1988), with the following changes. Dried samples in test tubes were redissolved in $0.2 \mathrm{ml}$ of $100 \%$ ethanol. To each tube, $0.2 \mathrm{ml}$ of $0.2 \mathrm{M}$ linoleic acid was added. After adding $\mathrm{KH}_{2} \mathrm{PO}_{4}$, $1.5 \mathrm{ml}$ of $0.2 \mathrm{~mm} \mathrm{FeSO}_{4}$ was added to each emulsion to initiate the reaction. Samples were incubated at $37 \mathrm{C}$ for $3 \mathrm{~h}$. To clear the emulsion, $2 \mathrm{ml}$ of $0.1 \mathrm{~N} \mathrm{NaOH}$ was added. Results of the assay are reported as percentage inhibition of lipid oxidation. Absorbance at $232 \mathrm{~nm}$ measures conjugated dienes and is an indicator of oxidation. The standard curve with $\alpha$-tocopherol showed that oxidation decreased in this system with increased antioxidant concentrations. We assume here that changes in oxidation caused by sample additions to the system were due to the presence of lipid-soluble antioxidants rather than the presence of less pro-oxidants. However, care should be taken in interpreting these results.

$\alpha$-Tocopherol. $\alpha$-Tocopherol content was determined by the HPLC method of Spychalla and Desborough (1990), modified as follows. Freeze-dried peel $(1 \mathrm{~g})$ was mixed by agitation with $25 \mathrm{ml}$ of $80 \%$ ethanol in water (v/v) and the filtrate was mixed with $10 \mathrm{ml}$ of petroleum ether. The mobile phase in HPLC was $97 \%$ methanol at a flow rate of $2 \mathrm{ml} \cdot \mathrm{min}^{-1}$. Samples were compared to external standards.

Total water-soluble reducing capacity (TWRC). TWRC was determined by monitoring iron reduction using an unpublished colorimetric method (S. Meir, personal communication). Freeze-dried samples $(0.05 \mathrm{~g})$ were homogenized in $10 \mathrm{ml}$ of acetate buffer ( $\mathrm{pH} 4.5$ ) and centrifuged for $10 \mathrm{~min}$ at $1800 \times \mathrm{g}$. Aliquots $(0.1 \mathrm{ml})$ of extract, $0.9 \mathrm{ml}$ of buffer, and $1 \mathrm{ml}$ of $\mathrm{FeCl}_{3}$ (made up as $24.3 \mathrm{mg} / 100 \mathrm{ml} \mathrm{H}_{2} \mathrm{O}+50 \mu \mathrm{H}_{2} \mathrm{SO}_{4}$ ) were placed in tubes and allowed to incubate in darkness at room temperature for $24 \mathrm{~h}$. After incubation, $0.8 \mathrm{ml}$ of $1.3 \mathrm{M}$ ammonium acetate and 0.2 $\mathrm{ml}$ of ferrozine reagent $\{75 \mathrm{mg}$ ferrozine [3-(2-pyridyl)-5-6-bis (4-phenyl-sulfonic acid)1,2,4-triazine] and $75 \mathrm{mg}$ Neocuproine (Sigma, St. Louis) were added. The absorbance at $562 \mathrm{~nm}$ was measured $1 \mathrm{~h}$ after adding ferrozine. Total reducing capacity (units/g dry weight) was defined as the $\mathrm{Fe}^{+3}$-reducing capacity of the tissue resulting in the absorbance of $1 \mathrm{OD}$ at $562 \mathrm{~nm}$.

Ascorbic acid. Ascorbic acid content was determined by a modification of the colorimetric method of Arakawa et al. (1981), as modified by Senaratna et al. (1988). Samples (0.1 g) were extracted in $10 \mathrm{ml}$ of $5 \%$ trichloroacetic acid and centrifuged, and the step to convert dehydroascorbic acid to ascorbic acid was omitted.

Glutathione. Glutathione content was determined using the HPLC procedure of Buwalda et al. (1988), as modified by Hariyadi and Parkin (1991), with the following changes. Freeze-dried apple peel $(0.5 \mathrm{~g})$ was extracted in $10 \mathrm{ml}$ of $80 \mathrm{~mm}$ sulfosalicylic acid with $1 \mathrm{~mm}$ EDTA. The sulfosalicylic acid and EDTA were dissolved separately and then mixed to avoid insolubility. Samples were centrifuged at $27,000 \times g$ for $15 \mathrm{~min}$ and filtered through a $0.45 \mu \mathrm{m}$ nylon filter. 5,5'-Dithio-bis (2-nitrobenzoic acid) was dissolved at $\mathrm{pH} 8.0$ and then brought to $\mathrm{pH}$ 7.0. Samples were derivatized for 5 min and then neutralized. The HPLC column was a C18 reversephase $250 \times 4$.0-mm column (Phenomenex, Torrance, Calif.) at $22 \mathrm{C}$. The mobile phase was $2 \%$ acetonitrile in $30 \mathrm{~mm}$ sodium phosphate buffer, $\mathrm{pH} 7.0$, with a flow rate of $1 \mathrm{ml} \cdot \mathrm{min}^{-1}$. Absorbance was determined at $280 \mathrm{~nm}$ and compared to external standards. A 7-min cleaning phase with $33 \%$ acetonitrile was run after each sample.

Carotenoids. Carotenoids were determined by extracting $0.5 \mathrm{~g}$ of freeze-dried peel tissue in $10 \mathrm{ml}$ of hexane. The samples in hexane were placed in vials, purged with $\mathrm{N}$, left in darkness at room temperature for $2 \mathrm{~h}$, and centrifuged at $39,000 \times g$ to remove all cloudiness. Absorbance was measured at $440 \mathrm{~nm}$, and an extinction coefficient of 2500 was used to calculate the concentrations.

Statistical analyses. Blocking was done where possible and, in experiments involving treatments, randomly selected trees (replications) were treated. Statistical analyses included analyses of variance, correlations, and analyses of covariance, where appropriate. The analyses of covariance were run using replications as the noncontinuous independent variable and the other variable as the continuous covariate. Because the replication effect was not of interest, results were interpreted using the variance associated with the linear or quadratic covariates, presented as a percentage of the total variance with replication removed (i.e., percentage of the nonreplicate sums of squares). SAS Statistical Software (SAS Institute, Cary, N.C.) was used to analyze the data.

\section{Results}

Estimates of antioxidant activity in apple peel at harvest. As harvest progressed, the OD 200 values, percentage inhibition of lipid oxidation (as indications of lipid-soluble antioxidant activity), and TWRC increased in fruit peel of both cultivars (Table 1). Preharvest hours at $<10 \mathrm{C}$ increased linearly with delayed harvest, and these hours were related strongly to all three antioxidant estimates. The OD 200 values were correlated strongly with percentage inhibition of lipid oxidation in both cultivars $(r=0.90$ and 0.85 for 'Cortland' and 'Delicious', respectively).

Scald susceptibility decreased markedly with later harvest (Table 1). Covariance of OD 200 values and scald was highly significant in both cultivars. In preliminary studies, the covariance of OD 200 and scald also was significant in 1988 and $1989(P \leq$ 0.01 ) for 'Cortland' and for 'Delicious' in $1988(P \leq 0.05)$ (data not shown). Scald vs. percentage inhibition of oxidation was significant for 'Cortland' and 'Delicious' apples in 1990. In 1989, however, these correlations were not significant (data not shown). TWRC values were correlated significantly with scald development, although they accounted for a smaller portion of the nonreplicate variance in scald than percentage inhibition of lipid oxidation (Table 1).

Ethephon greatly increased fruit ripeness, as shown by starch hydrolysis, internal ethylene concentrations, and fruit firmness (Barden and Bramlage, 1994). The at-harvest OD 200 values were much higher after ethephon treatment, as were the percentage inhibition of lipid oxidation values (Table 2). TWRC values also were increased by treatment. At least $90 \%$ of the fruit developed scald, although ethephon produced a significant reduction. Covariance analysis showed that percentage inhibition of lipid oxidation was significant, but accounted for only $32 \%$ of the nonreplicate variance in scald development, a result indicating a relatively weak relationship (data not shown). In this experiment, TWRC values were not correlated with scald development. From these results, ethephon-induced ripening seemed to increase antioxidant activity in apple peel, with a greater effect on lipid-soluble than water-soluble compounds. However, little resistance to scald was associated with these changes.

Mid-August bagging had no effect on fruit ripeness at harvest (Barden and Bramlage, 1994), but it resulted in substantially greater scald susceptibility of the fruit (Table 3). Bagging had no significant effect on OD 200 values or percentage inhibition of lipid oxidation, but it decreased TWRC. Thus, bagging seemed to a) reduce the accumulation of water-soluble antioxidants in the fruit, b) not influence lipid-soluble antioxidant levels, and c) increase scald susceptibility greatly.

Measurements of specific antioxidants in apple peel at harvest. 
Table 1. At-harvest estimates of antioxidant activity in peel from 'Cortland' and 'Delicious' apples and scald development after storage for 20 weeks at 0C in 1990. Relationships are shown as a percentage of nonreplicate sums of squares (SS) with the linear (L) or quadratic (Q) portions of the model or both.

\begin{tabular}{|c|c|c|c|c|c|c|c|}
\hline Statistic & $\begin{array}{c}\text { Harvest } \\
\text { date }\end{array}$ & $\begin{array}{l}\text { Hours } \\
<10 \mathrm{C}\end{array}$ & $\begin{array}{c}\text { OD } 200 \\
\left(\mathrm{OD} \times 1000 / \mathrm{cm}^{2}\right)\end{array}$ & $\begin{array}{l}\text { Oxidation }^{2} \\
\text { (\% inhibition) }\end{array}$ & $\begin{array}{c}\text { TWRC }^{\mathrm{y}} \\
\text { (units/g dry wt) }\end{array}$ & $\begin{array}{l}\text { Scald } \\
(\%)\end{array}$ & $\begin{array}{l}\text { Scald } \\
\text { score }^{x}\end{array}$ \\
\hline \multicolumn{8}{|c|}{ Cortland } \\
\hline & 17 Sept. & 21 & 5.5 & 40 & 11.2 & 98 & 2.7 \\
\hline & 24 Sept. & 79 & 7.7 & 60 & 11.3 & 78 & 1.9 \\
\hline & 3 Oct. & 127 & 17.9 & 76 & 12.0 & 46 & 1.6 \\
\hline & 11 Oct. & 150 & 23.5 & 87 & 13.8 & 49 & 1.6 \\
\hline Covariance with hours & & & $\mathrm{L}^{* * *} \mathrm{Q}^{* * *}$ & $\mathrm{~L}^{* * * *}$ & $\mathrm{~L}^{* * *} \mathrm{Q}^{*}$ & $\mathrm{~L}^{* * *}$ & $\mathrm{~L}^{* * *}$ \\
\hline Percentage nonreplicate SS & & & $97 \%$ & $93 \%$ & $69 \%$ & $82 \%$ & $66 \%$ \\
\hline Covariance with scald & & & $\mathrm{L}^{* * *}$ & $\mathrm{~L}^{* *}$ & $\mathrm{~L}^{* *}$ & & \\
\hline Percentage nonreplicate SS & & & $78 \%$ & $71 \%$ & $45 \%$ & & \\
\hline \multicolumn{8}{|c|}{ Delicious } \\
\hline & 21 Sept. & 62 & 2.4 & 22 & 13.9 & 94 & 2.7 \\
\hline & 26 Sept. & 104 & 5.5 & 34 & 14.1 & 88 & 2.8 \\
\hline & 3 Oct. & 127 & 10.9 & 44 & 14.9 & 68 & 2.1 \\
\hline & 11 Oct. & 150 & 18.1 & 55 & 15.8 & 51 & 1.7 \\
\hline Covariance with hours & & & $\mathrm{L}^{* * * *}$ & $\mathrm{~L}^{* * * *}$ & $\mathrm{~L}^{* *}$ & $\mathrm{~L}^{* * *} \mathrm{Q}^{*}$ & $\mathrm{~L}^{* * *} \mathrm{Q}^{* * *}$ \\
\hline Percentage nonreplicate SS & & & $98 \%$ & $86 \%$ & $60 \%$ & $79 \%$ & $76 \%$ \\
\hline Covariance with scald & & & $\mathrm{L}^{* * * *}$ & $\mathrm{~L}^{* *}$ & $\mathrm{~L}^{* *}$ & & \\
\hline Percentage nonreplicate SS & & & $76 \%$ & $68 \%$ & $60 \%$ & & \\
\hline
\end{tabular}

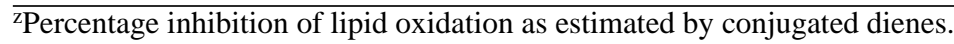

yTWRC $=$ total water-soluble reducing capacity.

${ }^{\mathrm{x}}$ Score reflects percentage of surface affected: 1 is $\geq 1 \% \leq 10 \% ; 2$ is $\geq 11 \% \leq 33 \% ; 3$ is $\geq 34 \% \leq 66 \% ; 4$ is $\geq 67 \% \leq 100 \%$.

${ }^{*}, * *, * * *$ Significant at $P \leq 0.05,0.01$, or 0.001 , respectively.

Table 2. Effects of ethephon on estimates of antioxidant activity in peel of 'Cortland' apples at harvest and scald development after storage at 0C.

\begin{tabular}{|c|c|c|c|c|c|c|}
\hline $\begin{array}{l}\text { Harvest } \\
\text { date }\end{array}$ & $\begin{array}{l}\text { Ethephon } \\
\text { (ppm) }\end{array}$ & $\begin{array}{c}\text { OD } 200 \\
\left(\mathrm{OD} \times 1000 / \mathrm{cm}^{2}\right)\end{array}$ & $\begin{array}{l}\text { Oxidation }^{2} \\
\text { (\% inhibition) }\end{array}$ & $\begin{array}{c}\text { TWRC }^{\mathrm{y}} \\
\text { (units/g dry wt) }\end{array}$ & $\begin{array}{l}\text { Scald } \\
(\%)\end{array}$ & $\begin{array}{l}\text { Scald } \\
\text { score }^{x}\end{array}$ \\
\hline \multirow[t]{3}{*}{1 Sept. } & 0 & 4.2 & 61 & 9.6 & 97 & 2.4 \\
\hline & 250 & 28.8 & 89 & 11.2 & 90 & 2.8 \\
\hline & 500 & 32.1 & 88 & 11.6 & 92 & 2.8 \\
\hline \multirow[t]{3}{*}{6 Sept. } & 0 & 6.0 & 62 & 11.3 & 99 & 2.4 \\
\hline & 250 & 29.5 & 90 & 13.9 & 91 & 3.2 \\
\hline & 500 & 33.9 & 91 & 14.2 & 96 & 3.2 \\
\hline \multicolumn{7}{|l|}{ Significance } \\
\hline Ethephon & & $* * *$ & $* * *$ & $*$ & $* *$ & $* * *$ \\
\hline
\end{tabular}

${ }^{\mathrm{Z}}$ Percentage inhibition of lipid oxidation as estimated by conjugated dienes.

yTWRC $=$ total water-soluble reducing capacity.

${ }^{\mathrm{x}}$ Score reflects percentage of surface affected: 1 is $\geq 1 \% \leq 10 \% ; 2$ is $\geq 11 \% \leq 33 \% ; 3$ is $\geq 34 \% \leq 66 \% ; 4$ is $\geq 67 \% \leq 100 \%$.

*,**,*** Significant at $P \leq 0.05,0.01$, or 0.001 , respectively, by analysis of variance.

Table 3. Effects of mid-August bagging of 'Cortland' apples on at-harvest estimates of antioxidant activity in peel and on scald development after storage at 0C, 1990.

\begin{tabular}{|c|c|c|c|c|c|c|c|}
\hline $\begin{array}{l}\text { Harvest } \\
\text { date }\end{array}$ & Treatment & $\begin{array}{l}\text { Hours } \\
<10 \mathrm{C}\end{array}$ & $\begin{array}{c}\text { OD } 200 \\
\left(\mathrm{OD} \times 1000 / \mathrm{cm}^{2}\right)\end{array}$ & $\begin{array}{l}\text { Oxidation }^{2} \\
\text { (\% inhibition) }\end{array}$ & $\begin{array}{c}\text { TWRC }^{\mathrm{y}} \\
\text { (units/g dry wt) }\end{array}$ & $\begin{array}{l}\text { Scald } \\
(\%)\end{array}$ & $\begin{array}{l}\text { Scald } \\
\text { score }^{\mathrm{x}}\end{array}$ \\
\hline \multirow[t]{2}{*}{$\overline{1 \text { Oct. }}$} & Control & 107 & 20.5 & 37 & 10 & 31 & 1.4 \\
\hline & Bagged & 107 & 19.3 & 40 & 8 & 62 & 1.4 \\
\hline \multirow[t]{2}{*}{9 Oct. } & Control & 150 & 26.3 & 67 & 10 & 13 & 1.4 \\
\hline & Bagged & 150 & 26.3 & 49 & 7 & 42 & 1.2 \\
\hline \multicolumn{8}{|l|}{ Significance } \\
\hline Bagging & & NS & NS & $* * *$ & $*$ & NS & \\
\hline Hours & & $*$ & $* *$ & NS & NS & NS & \\
\hline Bagging $\times$ hours & & NS & $*$ & NS & NS & NS & \\
\hline
\end{tabular}

${ }^{\mathrm{z}}$ Percentage inhibition of lipid oxidation as estimated by conjugated dienes.

yTWRC $=$ total water-soluble antioxidant activity.

${ }^{\mathrm{x}}$ Score reflects percent of surface affected: 1 is $\geq 1 \% \leq 10 \% ; 2 \%$ is $\geq 11 \% \leq 33 \% ; 3$ is $\geq 34 \% \leq 66 \% ; 4$ is $\geq 67 \% \leq 100 \%$

Ns,*,**,**** Nonsignificant or significant at $P \leq 0.05,0.01,0.001$, respectively, by analysis of variance. 
The data in Tables 1 to 3 present only estimates of total lipid-soluble and water-soluble antioxidants in the fruit peel. The most abundant lipid-soluble antioxidants are $\alpha$-tocopherol and carotenoids, and the most abundant water-soluble antioxidants are ascorbic acid and glutathione (Larson, 1988; Winston, 1990). In 'Cortland', the $\alpha$-tocopherol concentration was highest in peel of fruit from the last harvest and in 'Delicious' from the last two harvests, but the concentration was not significantly related to scald development (Table 4). Carotenoids increased with hours at $<10 \mathrm{C}$ in 'Cortland' but not in 'Delicious'. Neither ascorbic acid nor glutathione changed significantly during harvest. Scald also was not correlated significantly with ascorbic acid or glutathione concentrations in apple peel at harvest; it was correlated with carotenoid concentrations in 'Delicious', but not in 'Cortland'.

Table 4. Antioxidant concentrations in peel of 'Cortland' and 'Delicious' apples at harvest, 1990. Relationships with scald are shown as the percentage of nonreplicate sums of squares (SS) with linear (L) or quadratic (Q) portions of the model or both.

\begin{tabular}{|c|c|c|c|c|c|c|c|c|}
\hline Statistic & $\begin{array}{c}\text { Harvest } \\
\text { date }\end{array}$ & $\begin{array}{l}\text { Hours } \\
<10 \mathrm{C}\end{array}$ & $\begin{array}{c}\alpha \text {-Tocopherol } \\
\left(\mu \mathrm{g} \cdot \mathrm{g}^{-1} \text { dry wt }\right)\end{array}$ & $\begin{array}{c}\text { Carotenoids } \\
\left(\mu \mathrm{g} \cdot \mathrm{g}^{-1} \text { dry wt }\right)\end{array}$ & $\begin{array}{c}\text { Ascorbic acid } \\
\left(\mu \mathrm{g} \cdot \mathrm{g}^{-1} \text { dry wt }\right)\end{array}$ & $\begin{array}{c}\text { Glutathione } \\
\left(\mu \mathrm{g} \cdot \mathrm{g}^{-1} \text { dry wt }\right)\end{array}$ & $\begin{array}{l}\text { Scald } \\
(\%)\end{array}$ & $\begin{array}{l}\text { Scald } \\
\text { score }^{\mathrm{z}}\end{array}$ \\
\hline \multicolumn{9}{|c|}{ Cortland } \\
\hline & 17 Sept. & 21 & 103 & 22 & 380 & 91 & 98 & 2.7 \\
\hline & 24 Sept. & 79 & 90 & 21 & 376 & 106 & 78 & 1.9 \\
\hline & 3 Oct. & 127 & 100 & 23 & 365 & 139 & 46 & 1.6 \\
\hline & 11 Oct. & 150 & 145 & 33 & 411 & 81 & 49 & 1.6 \\
\hline Covariance with hours & & & $\mathrm{L}^{* * * *}$ & $\mathrm{~L}^{* *} \mathrm{Q}^{* *}$ & NS & NS & $\mathrm{L}^{* * * *}$ & \\
\hline Percentage nonreplicate SS & & $76 \%$ & $65 \%$ & $17 \%$ & $19 \%$ & $82 \%$ & & \\
\hline Covariance with scald & & & NS & NS & NS & NS & & \\
\hline Percentage nonreplicate SS & & & $16 \%$ & $24 \%$ & $5 \%$ & $12 \%$ & & \\
\hline \multicolumn{9}{|c|}{ Delicious } \\
\hline & 21 Sept. & 62 & 72 & 18 & 624 & 39 & 94 & 2.7 \\
\hline & 26 Sept. & 104 & 69 & 15 & 600 & 39 & 88 & 2.8 \\
\hline & 3 Oct. & 127 & 78 & 17 & 592 & 55 & 68 & 2.1 \\
\hline & 11 Oct. & 150 & 78 & 20 & 603 & 35 & 51 & 1.7 \\
\hline Covariance with hours & & & $\mathrm{L}^{*}$ & NS & NS & NS & $\mathrm{L}^{* * *} \mathrm{Q}^{*}$ & \\
\hline Percentage nonreplicate SS & & & $35 \%$ & $25 \%$ & $20 \%$ & $15 \%$ & $79 \%$ & \\
\hline Covariance with scald & & & NS & $\mathrm{L}^{*} \mathrm{Q}^{* *}$ & NS & NS & & \\
\hline Percentage nonreplicate SS & & & $36 \%$ & $62 \%$ & $5 \%$ & $0 \%$ & & \\
\hline
\end{tabular}

${ }^{\mathrm{z}}$ Score reflects percentage of surface affected: 1 is $\geq 1 \% \leq 10 \% ; 2$ is $\geq 11 \% \leq 33 \% ; 3$ is $\geq 34 \% \leq 66 \% ; 4$ is $\geq 67 \% \leq 100 \%$. Ns,***,*** Nonsignificant or significant at $P \leq 0.05,0.01$, or 0.001 , respectively.

Table 5. Effects of ethephon treatments on concentrations of specific antioxidants in 'Cortland' apple peel at harvest, 1990.

\begin{tabular}{|c|c|c|c|c|c|}
\hline $\begin{array}{l}\text { Harvest } \\
\text { date }\end{array}$ & $\begin{array}{c}\text { Ethephon } \\
\text { (ppm) }\end{array}$ & $\begin{array}{c}\alpha \text {-Tocopherol } \\
\left(\mu \mathrm{g} \cdot \mathrm{g}^{-1} \text { dry wt }\right)\end{array}$ & $\begin{array}{l}\text { Carotenoids } \\
\left(\mu \mathrm{g} \cdot \mathrm{g}^{-1} \text { dry wt }\right)\end{array}$ & $\begin{array}{l}\text { Ascorbic acid } \\
\left(\mu \mathrm{g} \cdot \mathrm{g}^{-1} \text { dry wt }\right)\end{array}$ & $\begin{array}{c}\text { Glutathione } \\
\left(\mu \mathrm{g} \cdot \mathrm{g}^{-1} \text { dry wt }\right)\end{array}$ \\
\hline \multirow[t]{3}{*}{1 Sept. } & 0 & 79 & 25 & 423 & 87 \\
\hline & 250 & 120 & 31 & 493 & 98 \\
\hline & 500 & 116 & 27 & 511 & 83 \\
\hline \multirow[t]{3}{*}{6 Sept. } & 0 & 72 & 21 & 383 & 87 \\
\hline & 250 & 149 & 33 & 479 & 88 \\
\hline & 500 & 154 & 36 & 481 & 93 \\
\hline \multicolumn{6}{|l|}{ Significance } \\
\hline Ethephon & & $* * *$ & $\mathrm{NS}^{\mathrm{Z}}$ & $* * *$ & NS \\
\hline
\end{tabular}

${ }^{\mathrm{z} S i g n i f i c a n c e ~ l e v e l ~ f o r ~ b o t h ~ d a t e s ~ c o m b i n e d ~ a t ~} P=0.06$.

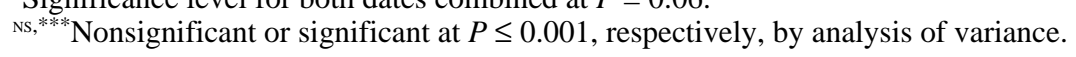

Table 6. Effects of mid-August bagging of 'Cortland' apples on at-harvest antioxidant concentrations in peel, 1990.

\begin{tabular}{|c|c|c|c|c|c|}
\hline $\begin{array}{l}\text { Harvest } \\
\text { date }\end{array}$ & Treatment & $\begin{array}{c}\alpha \text {-Tocopherol } \\
\left(\mu \mathrm{g} \cdot \mathrm{g}^{-1} \text { dry wt }\right)\end{array}$ & $\begin{array}{l}\text { Carotenoids } \\
\left(\mu \mathrm{g} \cdot \mathrm{g}^{-1} \text { dry wt }\right)\end{array}$ & $\begin{array}{l}\text { Ascorbic acid } \\
\left(\mu \mathrm{g} \cdot \mathrm{g}^{-1} \text { dry wt }\right)\end{array}$ & $\begin{array}{c}\text { Glutathione } \\
\left(\mu \mathrm{g} \cdot \mathrm{g}^{-1} \text { dry wt }\right)\end{array}$ \\
\hline \multirow[t]{2}{*}{1 Oct. } & Control & 106 & 23 & 399 & 102 \\
\hline & Bagged & 91 & 18 & 324 & 117 \\
\hline \multirow[t]{2}{*}{9 Oct. } & Control & 122 & 30 & 384 & 103 \\
\hline & Bagged & 93 & 17 & 297 & 84 \\
\hline \multicolumn{6}{|l|}{ Significance } \\
\hline Bagging & & $*$ & $*$ & $* * *$ & NS \\
\hline Hours & & $* *$ & NS & NS & NS \\
\hline Bagging $\times$ hours & & $*$ & NS & NS & NS \\
\hline
\end{tabular}

NS, ${ }^{* * *, * * * *}$ Nonsignificant or significant at $P \leq 0.05,0.01,0.001$, respectively, by analysis of variance. 
Ethephon-induced ripening increased $\alpha$-tocopherol and ascorbic acid but not glutathione concentrations in fruit peel (Table 5). Carotenoids also seemed to increase with ethephon treatment, but only for the 6 Sept. harvest $(P=0.06)$. Relationships between ethephon concentration and $\alpha$-tocopherol and ascorbic acid were linear (data not shown). These data, along with the antioxidant estimates (Table 2), indicated that lipid- and water-soluble antioxidants were increased by fruit ripening.

Bagging decreased $\alpha$-tocopherol, carotenoid, and ascorbic acid, but not glutathione, concentrations in apple peel (Table 6). The lack of significance for the latter undoubtedly is related to the opposite trends for the two harvest dates. These results showed that low light levels decreased lipid-soluble and water-soluble antioxidants, as also was indicated by the antioxidant estimates (Table 3 ).

\section{Discussion}

Estimates of antioxidant activity. OD 200 values increased greatly as harvest was delayed (Table 1) and as ripening was induced by ethephon (Table 2). Although increasing OD 200 values were correlated with increasing hours at $<10 \mathrm{C}$ (Table 1 ), the greatest increases occurred during the late harvests, as fruit were ripening. Furthermore, in the absence of any hours at $<10 \mathrm{C}$, ethephon induced substantially higher OD 200 values in fruit peel than those for the sequential-harvests experiment (34 vs. 24 for final harvests of 'Cortland'). Thus, OD 200 values seem to have been influenced more strongly by ripening (or ethylene) than by low temperature. Since bagging had no effect on OD 200 values (Table 3), light levels evidently had little or no influence on their increase.

Meir and Bramlage (1988) proposed that OD 200 values are estimates of lipid-soluble antioxidant activity. In these experiments, the OD 200 values always were correlated highly with percentage inhibition of lipid oxidation $(r=0.90,0.81,0.95$, and $0.67 ; P \leq 0.001)$. However, both of these estimates represent gross changes and may reflect differences in components other than antioxidants, such as changes in lipid composition of surface coatings. Neither OD 200 nor percentage inhibition values were correlated consistently with either $\alpha$-tocopherol or carotenoid concentrations in these experiments (data not shown).

TWRC, another estimate of gross changes, also increased during the season as hours at $<10 \mathrm{C}$ increased and ripening progressed (Table 1). The increase between the first and last harvest was almost $20 \%$ in 'Cortland' and somewhat $<20 \%$ in 'Delicious', and the TWRC values were correlated with scald development in both cultivars. TWRC also increased $\approx 20 \%$ with ethephon treatment in the absence of low temperature, but was not correlated with scald development $[r=(-0.18)$, nonsignificant $]$ (Table 2). Bagging decreased TWRC $\approx 20 \%$, and these reductions were correlated with greater scald development $[r=(-0.54), P \leq 0.05]$. Therefore, it seems that TWRC values were influenced more by ripening and light than by low temperature, and they were not correlated consistently with scald susceptibility.

Measurements of specific antioxidants. Concentrations of $\alpha$ tocopherol measured in apple peel were similar to those reported by Gallerani et al. (1990). They increased with sequential harvests of both cultivars and were correlated significantly with hours at $<10 \mathrm{C}$, although they accounted for a relatively small portion of the nonreplicate variance (Table 4). Starch indexes also were correlated significantly with $\alpha$-tocopherol (data not shown), and the greatest increase in $\alpha$-tocopherol came between harvests 3 and 4 , when fruit were ripening rapidly. Ethephon increased $\alpha$-tocopherol concentration (Table 5), and the apples treated with ethep- hon and harvested on 6 Sept. had slightly more $\alpha$-tocopherol than did those harvested on 11 Oct. in the sequential-harvest experiment (Table 4). These data suggest that ripening was a primary contributor to increased $\alpha$-tocopherol concentrations in apple peel. Results of the bagging experiment (Table 6) indicated that relatively high light levels were required for high $\alpha$-tocopherol concentrations to accumulate in peel, since they were decreased by bagging. Only in the bagging experiment was scald correlated with $\alpha$-tocopherol concentration. Thus, it seemed that, in these experiments, $\alpha$-tocopherol alone did not play as large a role in the development of scald resistance as has been proposed previously (Anet, 1974; Gallerani et al., 1990; Meir and Bramlage, 1988).

Carotenoids, the other major contributor to lipid-soluble antioxidant activity (Winston, 1990), underwent changes similar to those of $\alpha$-tocopherol. They increased with hours at <10C (Table 4 ) and with ethephon treatment $(P=0.06)$ (Table 5), the magnitude of increase being similar in both cases. Bagging decreased carotenoids by $20 \%$ and $40 \%$ at the first and second harvest, respectively (Table 6). In the sequential-harvest and ethephon experiments, carotenoids were not correlated significantly with scald [ $r$ $=(-0.34),-0.26$, and -0.21 , for 'Cortland', 'Delicious', and ethephon experiments, respectively], but in the bagging experiment a negative correlation existed $[r=(-0.65), P \leq 0.01]$.

Ascorbic acid concentrations did not change significantly during sequential harvests of either 'Cortland' or 'Delicious' (Table 4). Ethephon treatments, however, increased concentrations by $\approx 20 \%$ (Table 5), while bagging fruit decreased concentrations by $\approx 20 \%$ (Table 6). These data indicate that ripening can increase ascorbic acid concentration in apple peel and that low light levels can reduce it. Scald was not correlated significantly with ascorbic acid concentrations in peel of either 'Cortland' or 'Delicious' in the sequential-harvest experiments (Table 4). In the ethephon and bagging experiments, however, significant correlations existed $[r$ $=(-0.44)$ and $-0.54, P \leq 0.05$, respectively]. Albrigo (1968) found that the red sides of apples contained higher ascorbic acid concentrations than the green sides, and that scald occurred more frequently on the green than on the red sides. Therefore, a strong correlative case can be made for a protective role of ascorbic acid against scald development, but low temperature does not seem to enhance its accumulation significantly in apple peel.

Glutathione concentration was not influenced consistently by low temperatures, was not affected by ethephon treatment or bagging of fruit, and was not related consistently to scald or to any of the other constituents that were measured. Therefore, it seems that glutathione concentration may not play a direct role in development of scald resistance.

The putative estimates of lipid-soluble antioxidant activity (OD 200 and percentage inhibition of lipid oxidation) indicated much greater changes in response to delayed ripening and ethephon treatment than were attributable to $\alpha$-tocopherol or carotenoids, the most abundant of these compounds. Conversely, these estimates did not reflect the reductions of $\alpha$-tocopherol and carotenoids that occurred in the bagged fruit. These estimates apparently are influenced extensively by other compounds, especially those that increased during ripening. In contrast, changes in the TWRC values seemed to reflect relatively closely the changes that occurred in ascorbic acid concentrations.

\section{Conclusion}

These data indicate that ripening substantially increased and bagging substantially decreased concentrations of $\alpha$-tocopherol, carotenoids, and ascorbic acid in apple peel. Increasing hours at 
<10C apparently also increased antioxidant concentrations, as indicated by estimates of total activity, but temperature affected antioxidants less than ripening and light. Changes in $\alpha$-tocopherol, carotenoids, and ascorbic acid were at least as great during ripening at 10C (Table 5) as during ripening at <10C (Table 4). However, during these experiments, scald susceptibility was affected more by increasing hours at $<10 \mathrm{C}$ than by ethephon-induced ripening or bagging (Barden and Bramlage, 1993), so the effects of low temperature in reducing scald susceptibility may involve significantly more than an increased concentration of the principal antioxidants in apple peel.

\section{Literature Cited}

Albrigo, L.G. 1968. Apple scald and chemical changes as influenced by orchard night temperature and Alar. PhD diss. Rutgers Univ., New Brunswick, N.J. (Diss. Abstr. 69-7520.)

Anet, E.F.L.J. 1972. Superficial scald, a functional disorder of stored apples. IX. Effect of maturity and ventilation. J. Sci. Food Agr. 23:763-769.

Anet, E.F.L.J. 1974. Superficial scald, a functional disorder of stored apples. XI. Apple antioxidants. J. Sci. Food Agr. 25:299-304

Arakawa, N., K. Tsutsumi, N. G. Sanceda, K. Kurata, and C. Inagaki. 1981. A rapid and sensitive method for the determination of ascorbic acid using 4,7-diphenyl-1,10-phenanthroline. Agr. Biol. Chem. 45:12891290.

Barden, C.L. and W.J. Bramlage. 1994. Separating the effects of cool temperatures, ripening, and light on development of scald resistance in apples before harvest. J. Amer. Soc. Hort. Sci. 119:54-58.

Bramlage, W.J., C.L. Barden, and C.B. Watkins. 1993. Comparing potential predictors of scald susceptibility of apples (Malus domestica, Borkh.). Acta Hort. 326:237-244.

Buwalda, F., L.J. De Kok, I. Stulen, and P.J.C. Kuiper. 1988. Cysteine, $\gamma$-glutamyl-cysteine and glutathione contents of spinach leaves as affected by darkness and application of excess sulfur. Physiol. Plant. 74:663-668.
Gallerani, G., G.C. Pratella, and R.A. Budini. 1990. The distribution and role of natural antioxidant substances in apple fruit affected by superficial scald. Adv. Hort. Sci. 3:144-146.

Hariyadi, P. and K.L. Parkin. 1991. Chilling-induced oxidative stress in cucumber fruit. Postharvest Biol. Technol. 1:33-45.

Huelin, F.E. and I.M. Coggiola. 1968. Superficial scald, a functional disorder of stored apples. IV. Effect of variety, maturity, oiled wraps and diphenylamine on the concentration of a-farnesene in the fruit. J. Sci. Food Agr. 19:297-301.

Huelin, F.E. and I.M. Coggiola. 1970. Superficial scald, a functional disorder of stored apples. VII. Effect of applied $\alpha$-farnesene, temperature and diphenylamine on scald and the concentration and oxidation of $\alpha$-farnesene in the fruit. J. Sci. Food Agr. 21:584-589.

Huelin, F.E. and K.E. Murray. 1966. $\alpha$-Farnesene in the natural coating of apples. Nature (London) 210:1260-1261.

Larson, R. A. 1988. The antioxidants of higher plants. Phytochemistry 27:969-978

McKersie, B.D., W.D. Beversdorf, and P. Hucl. 1982. The relationship between ozone insensitivity, lipid-soluble antioxidants, and superoxide dismutase in Phaseolus vulgaris. Can. J. Bot. 60:2686-2691.

Meigh, D.F. and A.A.E. Filmer. 1969. Natural skin coating of the apple and its influence on scald in storage. III. $\alpha$-Farnesene. J. Sci. Food Agr. 20:139-143.

Meir, S. and W.J. Bramlage. 1988. Antioxidant activity in 'Cortland' apple peel and susceptibility to superficial scald after storage. J. Amer. Soc. Hort. Sci. 113:412-418.

Senaratna, T., C.E. Mackay, B.D. McKersie, and R.A. Fletcher. 1988. Uniconazole-induced chilling tolerance in tomato and its relationship to antioxidant content. J. Plant Physiol. 133:56-61.

Spychalla, J.P. and S.L. Desborough. 1990. Superoxide dismutase, catalase, and $\alpha$-tocopherol content of stored potato tubers. Plant Physiol. 94:1214-1218.

Winston, G.W. 1990. Physiochemical basis for free radical formation in cells: Production and defenses, p. 57-86. In: R.G. Alscher and J.R. Cummings (eds.). Stress responses in plants. Adaptation and acclimation mechanisms. Wiley-Liss, New York. 